\title{
Polymorphonuclear Cell Infiltrate
}

National Cancer Institute

\section{Source}

National Cancer Institute. Polymorphonuclear Cell Infiltrate. NCI Thesaurus. Code C35982.

A morphologic finding referring to an acute inflammatory infiltrate that is composed of polymorphonuclear cells. 